\title{
On a dinosaur axis from one of the oldest dinosaur-bearing sites worldwide
}

Rodrigo T. Müller, Flávio A. Pretto, Micheli Stefanello, Eduardo Silva-Neves, and Sérgio Dias-Da-Silva Acta Palaeontologica Polonica 62 (3), 2017: 543-548 doi:https://doi.org/10.4202/app.00369.2017

The axial skeleton is proportionally underrepresented in the fossil record of early dinosaurs, when compared to other skeletal parts (e.g., pelvic girdle and hindlimb). For instance, the axis is poorly known in early dinosaurs, which precludes a better understanding of this important anatomical structure. Therefore, the present contribution fills an important gap with a description of the axis of a new early dinosaur (CAPPA/UFSM 0179). The specimen was collected at the Buriol outcrop, a Triassic fossiliferous locality from southern Brazil (Candelária Sequence, Santa Maria Supersequence) biostratigraphically correlated to Carnian units, placing this specimen among the oldest dinosaurs worldwide. Notable features include the combination of a neural spine that bears an almost straight dorsal margin along its length and presence of an epipophysis. This axis arrangement is unique among Carnian dinosaurs, representing a new morphotype, though a similar morphology is observed in some early theropods. Indeed, a phylogenetic analysis nested the specimen within Theropoda. However, this outcome is probably biased by the large amount of missing data in CAPPA/UFSM 0179 and also due to the limited sampling of the axis in early dinosaurs, particularly among sauropodomorphs. As the specimen comes from the site that includes Buriolestes schultzi (an early sauropodomorph), it is quite plausible that CAPPA/UFSM 0179 might be referable to that taxon. If so, the specimen improves the anatomical knowledge of Buriolestes schultzi, given its axis is yet unknown. An alternative possibility to be considered is that the specimen would belong to a dinosaur not yet known in the Candelária Sequence, which would increase its dinosaur diversity for the outcrop, improving the Triassic dinosaurian record from Southern Brazil.

Rodrigo Temp Müller [rodrigotmuller@hotmail.com], Micheli

Stefanello [michelistefanello@hotmail.com], and Eduardo Silva Neves [edusneves90@gmail.com ], Programa de Pós-Graduação em Biodiversidade Animal, Universidade Federal de Santa Maria, Av. Roraima, 1000, Bairro Camobi, 97105- 900 Santa Maria, RS, Brasil. Flávio Augusto Pretto [ flavio_pretto@yahoo.com.br] and Sérgio Dias da Silva [paleosp@gmail.com], Centro de Apoio à Pesquisa da Quarta Colônia, Universidade Federal de Santa Maria, Rua Maximiliano Vizzotto, 598, 97230-000 São João do Polêsine, RS, Brasil. 
This is an open-access article distributed under the terms of the Creative Commons Attribution License (for details please see creativecommons.org), which permits unrestricted use, distribution, and reproduction in any medium, provided the original author and source are credited.

Farif Full text $(486.9 \mathrm{kB})$ 